\title{
ANALISIS USAHATANI PADI SAWAH DI KABUPATEN MAGETAN PROVINSI JAWA TIMUR
}

\author{
Viona Ade Zarahma*, Sri Marwanti*, Ernoiz Antriyandarti*
}

\begin{abstract}
ABSTRAK
Penelitian ini bertujuan untuk mengetahui analisis usahatani padi sawah yang ada di Kabupaten Magetan, Provinsi Jawa Timur. Teknik pelaksanaan yang digunakan dalam penelitian adalah teknik survey. Metode pengambilan daerah sampel dilakukan dengan metode purposive, yaitu penentuan lokasi pengambilan daerah sampel diamabil secara sengaja berdasarakan pertimbangan-pertimbangan tertentu sesuai dengan tujuan penelitian. Penelitian ini dilakukan di Desa Gunungan, Kecamatan Kartoharjo, Kabupaten Magetan, Provinsi Jawa Timur. Jenis data primer dan sekunder. Teknik pengumpulan data secara observasi, wawancara dan pencatatan. Biaya usahatani dengan rata-rata luas lahan sebesar 0,90 hektar adalah $R p$ 11.312.100,00, dengan rata-rata biaya variabel sebesar $R p$ 5.317.000,00 dan rata-rata biaya tetap sebesar $R p$ 5.995.100,00. Rata-rata penerimaan usahatani adalah sebesar $R p$ 24.118.000,00. Rata-rata pendapatan usahatani adalah Rp12.805.900,00. Analisis BEP dan R/C Ratio menunjukkan bahwa usahatani yang dilakukan menguntungkan bagi petani yang ada di Desa Gunungan, Kecamatan Kartoharjo, Kabupaten Magetan, Provinsi Jawa Timur. Dengan angka $R / C$ ratio sebesar 2,13.
\end{abstract}

Kata Kunci : Analisis Usahatani, Usahatani Padi Sawah, Analisis BEP, R/C Ratio.

\section{ABSTRACT}

This study aims to determine the analysis of rice farming in Magetan Regency, East Java Province. The implementation technique used in the research is survey technique. The sampling area method was carried out using a purposive method, which is to determine the location of sampling area taken purposely based on certain considerations in accordance with the research objectives. The result come with farming costs with an average land area of 0.90 hectares are IDR. 11.312.100,00, with an average variable cost of IDR. 5.317.000,00 and the average fixed costs of IDR. 5.995.100,00. The average farm income is IDR. 24.118.000,00. The average farm income is IDR 12.805.900,00. BEP and R / C Ratio analysis showed that farming was carried out favorably for farmers in Gunungan Village, Kartoharjo District, Magetan Regency, East Java Province. With the R / C ratio of 2.13.

Key Words : Farming Analysis, Rice farming, BEP Analysis, R/C Ratio.

\section{PENDAHULUAN}

Indonesia terkenal memiliki lahan pertanian dan iklim yang potensial untuk mengembangkan usaha pertanian. Banyak penduduk Indonesia yang menggantungkan hidupnya di sektor pertanian. Selain itu, pertanian merupakan sektor yang banyak menyerap tenaga kerja. Maka dari itu, pertanian menyumbang pendapatan yang besar untuk devisa negara.

Padi sawah merupakan salah satu tanaman pangan di Indonesia yang semakin banyak diperlukan oleh masyarakat. Permintaan akan beras itu sendiri akan semakin bertambah seiring dengan pertumbuhan penduduk. Propinsi Jawa Timur merupakan salah satu produsen utama beras nasional, selain Jawa Barat dan Jawa Tengah. Salah satu kawasan sentra padi di Jawa Timur adalah Karesidenan Madiun. 
Tabel 1. Rata-rata Luas Panen dan Produktivitas Padi Sawah di Karesidenan Madiun Provinsi Jawa Timur Tahun 2016

\begin{tabular}{|c|c|c|c|}
\hline No & Kabupaten / Kota & Luas Panen (ha) & $\begin{array}{c}\text { Produktivitas } \\
(\mathrm{kw} / \mathrm{ha})\end{array}$ \\
\hline 1. & Magetan & $51.276,0$ & 67,77 \\
\hline 2. & Madiun & $79.916,0$ & 62,84 \\
\hline 3. & Ngawi & $129.011,8$ & 62,27 \\
\hline 4. & Ponorogo & $73.731,0$ & 60,60 \\
\hline 5. & Madiun (Kota) & $2.450,3$ & 57,61 \\
\hline \multirow[t]{2}{*}{6.} & Pacitan & $22.907,5$ & 50,41 \\
\hline & Jumlah & $2.112 .563,0$ & 61,08 \\
\hline
\end{tabular}

Sumber : Jawa Timur dalam Angka, 2017

Berdasakan Tabel 1 menunjukkan bahwa produktivitas padi sawah tertinggi di karesidenan Madiun adalah Kabupaten Magetan dengan produktivitas padi sawah sebesar $67,77 \mathrm{kw} / \mathrm{ha}$ dan produktivitas terendah adalah kabupaten Pacitan dengan $50,41 \mathrm{kw} / \mathrm{ha}$. Berdasarkan Tabel 1 dapat dilihat bahwa dengan terbatasnya luas lahan yang ada d Kabupaten Magetan, produktivitas padi sawah di Kabupaten Magetan cukup maksimal. Selain itu, di Kabupaten Magetan sedang dijalankan program lumbung padi nasional dan rice milling dimana sedang gencar dilakukan kegiatan menanam padi sawah. Melalui program pemerintah tersebut diharapkan akan dapat memenuhi kebutuhan beras dalam negeri sehingga pemerintah tidak perlu impor dari negara lain. Penelitian ini bertujuan untuk mengetahui analisis usahatani padi sawah yang ada di Kabupaten Magetan, Provinsi Jawa Timur.

\section{METODE PENELITIAN Metode Dasar Penelitian}

Penelitian dilakukan di Desa Gunungan, Kecamatan Kartoharjo, Kabupaten Magetan yang dilakukan dengan pertimbangan bahwa Kecamatan Kartoharjo merupakan Kecamatan yang memiliki produksi padi sawah tertinggi di Kabupaten Magetan. Sedangkan Desa Gunungan memiliki produksi padi sawah tertinggi di Kecamatan Kartoharjo.

Metode pengambilan sample dilakukan secara simple random sampling.
Menurut Sugiyono (2017) dan Noor (2001) metode simple random sampling yaitu metode pengambilan anggota sampel dari populasi yang dilakukan secara acak tanpa memperhatikan strata yang ada dalam populasi tersebut. Populasi dalam penelitian ini yang akan dijadikan responden adalah petani padi sawah di Kelurahan/Desa Gunungan, Kecamatan Kartoharjo, Kabupaten Magetan, Jawa Timur. Hasil yang didapat tersebut adalah nilai karakteristik yang sesungguhnya (true value). Sampel yang diambil adalah sebanyak 30 responden petani yang diambil secara acak atau random yang ada di Desa Gunungan, Kecamatan Kartoharjo, Kabupaten Magetan, Provinsi Jawa Timur.

\section{Jenis dan Sumber Data}

Jenis dan sumber data yang digunakan adalah data primer dan data sekunder. Sumber data primer dari penelitian ini adalah sumber data yang berasal dari responden petani padi sawah yang ada di Desa Gunungan, Kecamatan Kartoharjo, Kabupaten Magetan, Provinsi Jawa Timur dengan tujuan agar memperoleh informasi mengenai identitas responden, biaya usahatani, penerimaan usahatani dan data-data lain yang menunjang penelitian mengenai usahatani padi sawah yang ada di Desa Gunungan, Kecamatan Kartoharjo, Kabupaten Magetan, Provinsi Jawa Timur. Sedangkan data sekunder diperoleh dari Badan Pusat Statistik (BPS) Kabupaten Magetan, Dinas 
Pertanian Kabupaten Magetan dan dari kantor Kecamatan Kartoharjo itu sendiri apabila terdapat kekurangan data yang ada karena Badan Pusat Statistik (BPS) Kabupaten Magetan memperoleh informasi mengenai produk-produk pertanian yang ada di Kecamatan Kartoharjo dari kantor Kecamatan Kartoharjo itu sendiri.

\section{Teknik Pengumpulan Data}

Teknik pengumpulan data melalui observasi, wawancara dan pencatatan. Teknik observasi melalui pengamatan di tempat penelitian langsung. Teknik wawancara melalui wawancara responden langsung dimana responden dalam penelitian ini yaitu petani yang menanam padi sawah di Desa Gunungan, Kecamatan Kartoharjo, Kabupaten Magetan, Provinsi Jawa Timur. Pertanyaan yang diajukan kepada petani juga terkait dengan karakteristik petani seperti nama, umur, pendidikan dan sebagainya. Hal ini diperlukan untuk melihat gambaran umum dari petani padi sawah yang ada di daerah penelitian. Sedangkan teknik pencatatan dilakukan melalui mencatat di kuisioner yang sudah dipersiapkan.

\section{Metode Analisis Data}

1. Mengetahui pendapatan usahatani

a. Biaya usahatani

Menurut Suratiyah (2015), biaya dalam usahatani terdapat dua macam yaitu biaya variabel (VC/Variable Cost) dan biaya tetap (FC/Fixed Cost). Biaya variabel meliputi biaya sarana produksi seperti pupuk, pestisida, tenaga kerja luar keluarga dan tenaga kerja keluarga. Sedangkan biaya tetap meliputi sewa lahan, biaya bunga, penyusutan per usahatani. Dapat dirumuskan sebagai berikut:

TC

$$
\begin{aligned}
& =\mathrm{VC}+\mathrm{FC} \\
& \text { Keterangan }: \\
& \mathrm{TC}=\text { Total biaya usahatani }(\mathrm{Rp}) \\
& \mathrm{VC}=\text { Biaya variabel }(\mathrm{Rp})
\end{aligned}
$$

$\mathrm{FC}=$ Biaya tetap $(\mathrm{Rp})$

b. Penerimaan usahatani

Menurut Suratiyah (2015), besarnya penerimaan usahatani yang diterima oleh petani dapat diketahui menggunakan rumus :

$=\mathrm{Y} \times \mathrm{P}$

Keterangan :

$\mathrm{TR}=$ Total penerimaan $(\mathrm{Rp})$

$\mathrm{Y}=$ Produksi total $(\mathrm{kw})$

$\mathrm{P} \quad=$ Harga produksi $(\mathrm{Rp})$

c. Pendapatan petani

Menurut Suratiyah (2015), besarnya pendapatan usahatani yang diterima oleh petani dapat diketahui menggunakan rumus :

$\mathrm{TR}-\mathrm{TC}$

$\mathrm{I}=$

Keterangan :

I = Pendapatan petani (Rp)

$\mathrm{TR}=$ Total penerimaan $(\mathrm{Rp})$

$\mathrm{TC}=$ Total biaya usahatani (Rp)

2. Kelayakan usahatani

a. Analisis BEP

Menurut Suratiyah (2015) dan Soekartawi (2002), dengan adanya BEP ini, petani dapat merencanakan segala sesuatunya karena dapat dihitung berapa produksi (kg) maupun peneriman (Rp) yang harus dicapai agar petani memperoleh keuntungan ( $\mathrm{Rp}$ ) atau keuntungan marjin (\%) dan juga dapat dihitung harga jual agar petani untung diatas biaya produksi atau dari total biaya produksi yang telah dikeluarkan petani. BEP ada empat perhitungan yaitu :

1) BEP Penerimaan $=$ $\frac{F C}{1-\frac{V C}{T R}}$

(4)

2) BEP Produksi = $\frac{F C}{P-A V C}$ 
3) BRP Harga = $\frac{T C}{Y}$

(6)

4) BEP Luas

$$
\frac{\text { Produksi BEP }}{\text { Produksi Riil }} x \text { luas lahan }
$$

(7)

Keterangan :

$\mathrm{FC}=$ Biaya tetap $(\mathrm{Rp})$

$\mathrm{VC}=$ Biaya variabel (Rp)

$\mathrm{S}=$ Total penerimaan (Rp)

$\mathrm{P} \quad=$ Harga produksi $(\mathrm{Rp})$

$\mathrm{AVC}=$ Biaya variabel per unit $(\mathrm{Rp} / \mathrm{kw})$

$\mathrm{Y}=$ Produksi total $(\mathrm{kw})$

b. R/C Ratio

$\mathrm{R} / \mathrm{C}$ ratio dikenal sebagai perbandingan antara penerimaan usahatani dengan biaya usahatani. Secara matematis dapat dituliskan sebagai berikut (Ohen dan Ajah, 2015)

$$
\mathrm{R} / \mathrm{C} \text { Ratio }=
$$

$\frac{R}{C}$

Keterangan :

$\mathrm{R}=$ Penerimaan $(\mathrm{Rp})$

$\mathrm{C}=$ Biaya yang dikeluarkan $(\mathrm{Rp})$

Kriteria :

$\mathrm{R} / \mathrm{C}>1$ berarti usahatani efisien

$\mathrm{R} / \mathrm{C}=1$ berarti usahatani dalam kondisi BEP atau titik impas

$\mathrm{R} / \mathrm{C}<1$ berarti usahatani padi sawah tidak efisien

\section{HASIL DAN PEMBAHASAN}

\section{Keadaan Geografi}

Kabupaten Magetan merupakan kabupaten yang terletak di ujung barat Provinsi Jawa Timur yang berbatasan dengan Provinsi Jawa Tengah. Secara astronomis, Kabupaten Magetan terletak di antara $7^{\circ}{ }^{\circ} 30^{\prime}$ Lintang Utara dan $7^{\circ}{ }^{\circ} 7^{\prime}$ Lintang Selatan, serta $111^{\circ} 10^{\prime}$ dan $111^{\circ} 30^{\prime}$ Bujur Timur. Wilayah Kabupaten Magetan berupa daratan yang memiliki luas wilayah sebesar $666,84 \mathrm{~km}^{2}$, yang terbagi atas 18
Kecamatan. Adapun batas wilayahnya yaitu 1) Sebelah Utara : Kabupaten Ngawi; 2) Sebelah Selatan : Kabupaten Ponorogo dan Kabupaten Wonogiri (Provinsi Jawa Tengah); 3) Sebelah Timur : Kabupaten Madiun; 4) Sebelah Barat : Kabupaten Karanganyar (Provinsi Jawa Tengah).

Menurut Balai Besar Tanaman Padi (2017), ketinggian tanaman padi yang baik adalah berkisar diantara 0 sampai dengan 1500 meter diatas permukaan air laut. Kabupaten Magetan berada pada ketinggian di antara 100 sampai dengan 135 meter diatas permukaan laut. Maka dari itu, Kabupaten Magetan cocok untuk budidaya padi, salah satunya adalah Kecamatan Kartoharjo sebagai tempat penelitian.

Luas Kecamatan Kartoharjo adalah $25,03 \mathrm{Km}^{2}$. Luas Desa Gunungan sebagai tempat penelitian adalah $2,38 \mathrm{Km}^{2}$. Lahan yang digunakan di Kecamatan Kartoharjo sebagian besar digunakan untuk sawah. Jumlah penduduk Kecamatan Kartoharjo sebanyak 26.004 jiwa dengan penduduk perempuan sebanyak 13.118 jiwa dan penduduk laki-laki sebanyak 12.886 jiwa. Rata-rata jumlah kepadatan penduduk per $\mathrm{Km}^{2}$ di Kecamatan Kartoharjo sebanyak 1.039 jiwa. Sarana dan prasarana pendidikan yang terdiri dari 3 jenjang pendidikan sebanyak 27 sekolah, dengan jumlah SD/MI sebanyak 23 sekolah, SMP/MTS sebanyak 2 sekolah dan SMA/MA sebanyak 2 sekolah.

Desa Gunungan, $\begin{array}{r}\text { Kecamatan } \\ \text { Magetan }\end{array}$
Kartoharjo, Kabupaten sengan
membudidayakan padi sawah den
varietas padi Inpari 4, Ciherang dan IR 64 .
Petani ditempat tersebut memilih padi
sawah vaerietas tersebut dengan tujuan
untuk mendapatkan hasil panen yang
sebanyak-banyaknya dengan kualitas yang
baik pula. Maka dari itu, tanaman padi
sawah yang ditanam harus sehat dan
tumbuh dengan subur. Selama proses
budidaya tanaman padi sawah senantiasa
diperhatikan mulai dari pemilihan benih
sampai dengan pemanenan agar dapat
terhindar dari serangan hama tanaman padi


sawah yang menyebabkan turunnya hasil produksi saat panen. Teknik budidaya tanaman padi sawah varietas Inpari 4, Ciherang dan IR 64 pada dasarnya sama yaitu : 1) Memilih benih berkualitas dan menyemainya; 2) Mengolah lahan; 3) Menanam; 4) Memelihara; 5) Memanen; 6) Pasca Panen.

\section{Karakteristik Responden}

Pendidikan merupakan faktor penting dalam proses penerapan teknologi serta keterampilan dalam melakukan usahatani padi sawah. Hal tersebut dikarenakan keterampilan tersebut berkaitan erat dengan Sumber Daya Manusia (SDM). Semakin tinggi pendidikan maka semakin memiliki Sumber Daya Manusia (SDM) yang berkualitas. Pendidikan responden petani padi sawah di Desa Gunungan, Kecamatan Kartoharjo, Kabupaten Magetan, Provinsi Jawa Timur beragam mulai dari SD, SMP, SMA dan Diploma/Sarjana. Pendidikan responden terbanyak yaitu SMP sebanyak 12 responden. Kemudian tertinggi kedua yaitu SD sebanyak 10 responden. Selanjutnya SMA sebanyak 7 responden. Dan yang paling sedikit adalah Sarjana hanya 1 responden.

Pendidikan responden petani padi sawah tersebut kebanyakan hanya SD dan SMP dikarenakan mereka tidak mempunyai biaya untuk bersekolah, sehingga putus ditengah jalan atau tidak bisa melanjutkan pendidikan ke jenjang yang lebih tinggi dan mereka lebih memilih untuk mengikuti jejak orang tuanya menjadi petani padi sawah mulai mereka masih kecil untuk membantu perekonomian keluarga mereka agar menjadi lebih baik. Sementara itu ada 1 orang lulusan Sarjana dan menjadi petani dikarenakan beliau merupakan Guru/PNS dan untuk mengisi waktu luangnya serta untuk bekal di masa tua atau setelah pensiun nanti, maka beliau mengerjakan sawah kecilnya.

Pendidikan responden petani padi sawah kurang tinggi, sehingga faktor pengalaman yang sudah bertahun-tahun lamanya tersebut menjadi faktor yang berperan utama di dalam melakukan usahatani di tempat tersebut. Selain itu, petani juga berbekal mendapatkan pelatihan dan sosialisasi dari penyuluh pertanian yang mengunjungi desa mereka untuk memperkenalkan teknologi pertanian yang baru ataupun memberikan informasi tentang teknik yang tepat dalam mengatasi berbagai permasalahan dalam melakukan usahatani para petani responden.

Rata-rata pengalaman responden petani padi sawah yang ada di Desa Gunungan cukup lama dan dapat dikatakan sudah cukup berpengalaman di bidang pertanian padi sawah. Dengan pengalaman petani yang cukup lama tersebut dirasa sudah faham secara fasih untuk melakukan usahatani padi sawah ataupun untuk menanggulangi permasalahan yang terjadi di lahan dalam melakukan usahatani padi sawah tersebut. Rata-rata pengalaman petani padi sawah yang ada bervariatif antara 0 sampai dengan 45 tahun. Lama pengalaman paling sebentar adalah 5 tahun yaitu sebanyak 2 responden. Lama pengalaman paling lama adalah 42 tahun yaitu sebanyak 2 responden. Tidak ada responden yang memiliki lama pengalaman antara 6 sampai dengan 10 tahun. Lama pengalaman antara 11 sampai dengan 20 tahun adalah sebanyak 3 responden. Kemudian lama pengalaman terbanyak adalah diantara 21 sampai dengan 40 tahun yaitu sebanyak 23 responden. Umumnya, responden petani di Desa Gunungan sudah berkeluarga atau menikah. Maka dari itu, mereka memiliki tanggungan entah itu istri atau suami maupun anak, untuk mencukupi kehidupan rumah tangganya tersebut. Namun ada 1 orang responden yang belum menikah, beliau membantu orang tuanya mengerjakan sawah tersebut setelah lulus SMA untuk mencukupi kebutuhan keluarganya karena kasihan dengan kondisi orang tuanya yang membanting tulang untuk mencari nafkah mencukupi kebutuhan rumah tangganya.Untuk memenuhi kebutuhan rumah tangga, 
responden petani ada yang memiliki pekerjaan sampingan sebanyak 8 orang dengan rincian PNS sebanyak 1 orang; tengkulak sebanyak 2 orang; supir, blantik sapi, pelayaran, kuli selepan dan pengeboran sumur masing-masing 1 orang.

Luas lahan berpengaruh terhadap produktivitas usahatani, dimana usahatani dengan luas lahan yang lebih besar akan memiliki produktivitas yang lebih tinggi dibandingkan dengan usahatani dengan luas lahan yang lebih kecil. Lahan pertanian responden padi sawah di Desa Gunungan semuanya milik pribadi, sehingga petani tidak perlu mengeluarkan biaya lagi untuk menyewa lahan kepada orang lain dan hanya membayar pajak kepada pemerintah setempat dengan harga yang telah ditentukan. Rata-rata luas lahan responden petani sebanyak 0,9 ha.

\section{Analisis Usahatani}

Biaya variabel merupakan biaya yang digunakan untuk membeli atau untuk menyediakan bahan baku yang habis dalam satu kali masa produksi. Untuk melakukan usahatani padi sawah, maka memerlukan

Tabel 2. Rata-rata Penggunaan Saprodi Padi Sawah di Desa Gunungan MT I per 0,90 ha

\begin{tabular}{llr}
\hline \hline & \multicolumn{1}{c}{ Soprodi } & Volume \\
\hline 1. & Benih & $26,67 \mathrm{~kg}$ \\
2. & Pestisida Antracol & $0,90 \mathrm{~kg}$ \\
3. & Pestisida Ares & $0,90 \mathrm{~L}$ \\
4. & Pestisida Prevathon & $1,10 \mathrm{~L}$ \\
5. & Pestisida Sankil & $1,15 \mathrm{~L}$ \\
6. & Pupuk Organik & $140 \mathrm{~kg}$ \\
7. & Pupuk Phonska & $91 \mathrm{~kg}$ \\
8. & Pupuk Urea & $248 \mathrm{~kg}$ \\
9. & Pupuk Za & $110 \mathrm{~kg}$ \\
\hline \hline
\end{tabular}

Sumber : Analisa Data Primer, 2018

Untuk mendapatkan sarana produksi, petani membelinya di Toko Pertanian setempat. Selain itu petani mendapatkan jatah pupuk Organik dari pemerintah sehingga petani dapat menghemat biaya usahatani padi sawah yang dilakukan dengan tidak perlu mengeluarkan biaya sepeserpun untuk pembelian pupuk Organik. Pupuk organik tersebut diberikan secara cuma-cuma atau gratis untuk responden petani padi sawah tersebut dikarenakan program yang tengah dijalankan oleh pemerintah setempat untuk petani. sarana produksi seperti benih, pupuk dan pestisida (Darus, et al., 2015). Benih yang digunakan responden petani padi sawah ada 3 macam jenis benih berkualitas yaitu padi varietas Ciherang, padi varietas IR 64, dan padi varietas Inpari 4. Kemudian untuk pupuk yang digunakan adalah pupuk Urea, Phonska, Za dan Organik. Lalu, untuk pestisida menggunakan pestisida cair maupun bubuk dengan merk dagang Ares, Prevathon, Antracol dan Sankil. Ares merupakan pestisida berjenis insektisida berbentuk cair digunakan untuk mengatasi hama wereng coklat pada tanaman padi sawah. Prevathon merupakan pestisida berjenis insektisida berbentuk cair untuk menanggulangi hama belalang dan walang sangit. Antracol merupakan pestisida berjenis fungisida berbentuk bubuk dilarutkan sendiri dengan air yang digunakan untuk mengendalikan penyakit jamur pada tanaman. Kemudian Sankil merupakan pestisida jenis insektisida berbentuk cair yang digunakan untuk mengatasi hama ulat pada tanaman. 
Tabel 3. Rata-rata Biaya Produksi Padi Sawah di Desa Gunungan MT I per 0,90ha

\begin{tabular}{llr}
\hline & \multicolumn{1}{c}{ No Saprodi } & Biaya (Rp) \\
\hline 1. & Benih & 410.000 \\
2. & Pestisida Antracol & 447.000 \\
3. & Pestisida Ares & 220.000 \\
4. & Pestisida Prevathon & 119.000 \\
5. & Pestisida Sankil & 0 \\
6. & Pupuk Organik & 117.000 \\
7. & Pupuk Phonska & 148.000 \\
8. & Pupuk Urea & 108.000 \\
9. & Pupuk Za & 92.000 \\
\hline & $\quad$ Jumlah & 1.661 .000 \\
\hline
\end{tabular}

Sumber : Analisa Data Primer, 2018

Desa Gunungan menggunakan sistem upah kerja bawon. Sistem upah bawon ini, pemilik lahan memberikan hasil panen dengan bagian tertentu kepada kelompok buruh penggarap, yang memang merupakan hak penuh dari buruh penggarap atas pekerjaan yang telah dilakukannya. Bagian tertentu tersebut adalah presentase hasil panen yang telah berbentuk gabah yang telah disepakati oleh pemilik lahan dan kelompok buruh penggarap, namun persentase ini tidak hanya merupakan kesepakatan antara kedua belah pihak tersebut, namun memang sebuah kesepakatan yang dianut oleh seluruh anggota masyarakat Desa Gunungan tersebut. Besar pembagian tersebut adalah $90 \%$ milik pemilik lahan dan $10 \%$ milik kelompok buruh penggarap tersebut untuk proses pemanenan yang dilakukan oleh kelompok buruh penggarap tersebut.

Tabel 4. Rata-rata Biaya Tenaga Kerja Padi Sawah di Desa Gunungan MT I per 0,90 ha

\begin{tabular}{llr}
\hline \hline No & \multicolumn{1}{c}{ Saprodi } & \\
\hline 1. & Pengolahan Lahan & Biaya (Rp) \\
2. & Penanaman & 667.000 \\
3. & Pemupukan & 71.000 \\
4. & Pengairan/Irigasi & 86.000 \\
5. & Penyemprotan & 84.000 \\
6. & Penyiangan & 94.000 \\
7. & Pemanenan & 2.412 .000 \\
\hline & $\quad$ Jumlah & 3.656 .000 \\
\hline \hline
\end{tabular}

Sumber : Analisa Data Primer, 2018

$\begin{array}{cccl}\text { Pengolahan lahan biasanya } & \begin{array}{l}\text { dengan bantuan alat berupa pembajak } \\ \text { sawah atau traktor. Kemudian untuk }\end{array} \\ \text { dilakukan secara } & \text { manual } \begin{aligned} \text { dengan } \\ \text { menggunakan alat berupa cangkul ataupun }\end{aligned} & \text { penanaman dilakuan oleh kelompok }\end{array}$


usahatani yang berjumlah sekitar 15 orang yang bergilir menanam dari satu sawah ke sawah lainnya dengan upah untuk banyaknya orang sekitar 15 orang tersebut Rp 300.000,00 per setengah bahu (atau 0,35 ha). Semakin luas lahannya maka biaya juga semakin besar biaya yang diperlukan. Untuk pemupukan, penyemprotan dan penyiangan biasanya dilakukan oleh pemilik lahan sendiri untuk menekan biaya, walaupun ada pula yang menggunakan bantuan buruh tani untuk melakukannya yang biasaya pemilik lahan yang memiliki lahan luas. Untuk melakukan proses pemupukan, penyemprotan dan penyiangan apabila dijumlahkan, responden petani padi sawah rata-rata mengeluarkan biaya sebanyak Rp 249.000,00. Untuk pemanenan dilakukan oleh kelompok tani seperti dalam penanaman padi namun untuk upah diberlakukan bagi hasil yaitu satu dibanding sepuluh yang apabila dikalkulasikan dengan angka maka responden petani padi sawah mengeluarkan rata-rata biaya untuk proses pemanenan yaitu sebanyak Rp 2.412.000,00.

Selain biaya variabel (sarana produksi dan biaya tenaga kerja), biaya yang harus dikeluarkan untuk usahatani padi sawah adalah biaya tetap yang meliputi biaya pajak dan lain-lain. Lain-lain disini berupa biaya sewa lahan, sewa alat produksi, dan penyusutan alat produksi.

Tabel 5. Rata-rata Biaya Tetap Usahatani Padi Sawah di Desa Gunungan MT I per 0,90 ha

\begin{tabular}{llr}
\hline \hline No & \multicolumn{1}{c}{ Saprodi } & Biaya (Rp) \\
\hline 1. & Pajak & 142.500 \\
2. & Sewa Lahan & 4.720 .000 \\
3. & Pembayaran Irigasi & 202.000 \\
4. & Sewa Traktor & 930.000 \\
5. & Penyusutan alat & 600 \\
\hline \multicolumn{2}{c}{ Jumlah } \\
\hline \hline
\end{tabular}

Sumber : Analisa Data Primer, 2018

Total biaya usahatani adalah jumlah dari seluruh biaya-biaya yang sudah dikeluarkan dalam melakukan suatu usahatani tersebut. Total biaya usahatani diperoleh melalui :

$$
\begin{aligned}
& \mathrm{TC}=\mathrm{VC}+\mathrm{FC} \\
& \mathrm{TC}=\operatorname{Rp} 5.317 .000,00+\mathrm{Rp} 5.995 .100,00 \\
& \mathrm{TC}=\operatorname{Rp} 11.312 .100,00
\end{aligned}
$$

Penerimaan usahatani adalah besaran hasil yang diterima petani sebelum dikurangi dengan biaya-biaya yang ada. Penerimaan usahatani dengan kata lain dapat disebut dengan pendapatan kotor.

$\mathrm{TR}=\mathrm{Y} \times \mathrm{P}$

$\mathrm{TR}=61,33 \mathrm{kw} \times \mathrm{Rp} 392.000,00 / \mathrm{kw}$

$\mathrm{TR}=\mathrm{Rp} 24.118 .000,00$

Berdasarkan perhitungan yang dilakukan, diperoleh jumlah produksi total
(Y) sebanyak 1840 kwintal dengan rata-rata jumlah produksi sebanyak 61,33 kw. Harga jual produksi $(\mathrm{P})$ bervariasi antara $\mathrm{Rp}$ 380.000,00 sampai dengan Rp 400.000,00 per kwintal sesuai dengan jenis padi sawah yang ditanam. Untuk varietas padi sawah IR64 dijual dengan harga Rp 380.000,00 per kwintal. Untuk varietas padi sawah Inpari4 dijual dengan harga Rp 390.000,00. Kemudian untuk varietas padi sawah Ciherang dijual dengan harga paling tinggi yaitu sebanyak Rp 400.000,00. Dari harga tersebut diperoleh rata-rata harga varietas padi sawah sebanyak Rp 392.000,00. Perhitungan penerimaan usahatani padi sawah di Desa Gunungan, Kecamatan Kawedanan, Kabupaten Magetan adalah sebanyak Rp 24.118.000,00. 
Pendapatan usahatani merupakan besaran hasil yang diterima petani setelah dikurangi dengan biaya-biaya yang ada. Pendapatan usahatani dengan kata lain dapat disebut dengan pendapatan bersih petani. Berdasarkan data yang sudah ada maka dapat dicari besaran jumlah pendapatan petani dari usahatani padi sawah yang dilakukan dalam satu kali masa tanam yaitu sebagai berikut ini:

$\mathrm{I}=\mathrm{TR}-\mathrm{TC}$

$\mathrm{I}=\mathrm{Rp} 24.118 .000,00-\mathrm{Rp} 11.312 .100,00$

$\mathrm{I}=\mathrm{Rp} 12.805 .900,00$

Total penerimaan padi sawah (TR) adalah $\mathrm{Rp}$ 24.118.000,00. Total biaya usahatani padi sawah (TC) sebesar Rp 11.312.100,00. Apabila jumlah tersebut dikurangkan maka hasil yang diperoleh adalah sebesar Rp 12.805.900,00. Jumlah tersebut yang dinamakan dengan pendapatan petani padi sawah (I).

\section{Kelayakan Usahatani}

Analisis BEP (Break-Even Point) adalah suatu analisis yang bertujuan untuk menemukan satu titik, yang terdapat dalam suatu unit atau nilai mata uang (rupiah), yang menunjukkan bahwa biaya sama dengan pendapatan. Dengan mengetahui analisis titik BEP, maka kita juga dapat mengetahui juga analisis volume penjualan, titik impas (yaitu tidak untung atau rugi) sehingga apabila penjualan melebihi hal tersebut maka pelaku usaha mulai mendapatkan untung lebih (Prasetya dan Lukistuti, 2009; Keukama dan Frynardo, 2017).

BEP dengan kata lain merupakan titik impas dimana posisi jumlah pendapatan dan biaya sama atau seimbang sehingga tidak terdapat keuntungan ataupun kerugian didalam melakukan suatu usahatani. BEP ini digunakan dalam menganalisis proyeksi sejauh mana banyaknya jumlah yang diproduksi atau sebanyak apa hasil (uang) yang harus diterima untuk mendapatkan titik impas atau kembali modal.
Untuk menghitung analisis BEP dapat diperoleh melalui empat komponen perhitungan. Empat komponen perhitungan BEP tersebut yaitu menghitung BEP penerimaan, BEP produksi, BEP harga, dan BEP Luas. Perhitungan analisis BEP sebagai berikut:

a. BEP Penerimaan

$$
\begin{aligned}
\text { BEP Penerimaan } & =\frac{F C}{1-\frac{V C}{T R}} \\
& =\frac{R p 5.995 .100,00}{1-\frac{R p 5.317 .000,00}{R p 24.118 .000,00}} \\
& =\frac{R p 5.995 .100,00}{1-0,2} \\
& =\frac{R p 5.995 .100,00}{0,8} \\
& =\operatorname{Rp} 7.493 .875,00 \\
& =\operatorname{Rp} 7.494 .000,00
\end{aligned}
$$

Berdasarkan perhitungan tersebut menjelaskan bahwa petani padi sawah di Desa Gunungan, Kecamatan Kartoharjo, Kabupaten Magetan, Provinsi Jawa Timur mengalami titik impas atau break even atau tidak untung atau rugi apabila responden mendapat penerimaan sebanyak $\mathrm{Rp}$ 7.494.000,00 untuk satu kali masa tanam. Jadi, responden mendapatkan keuntungan apabila mereka mendapatkan penerimaan dari penjualan padi sawah tersebut yang lebih besar dari Rp 7.494.000,00. Dan responden akan mengalami kerugian apabila hanya mampu mendapatkan penerimaan sebanyak Rp 7.494.000,00.

Berdasarkan data yang ada menunjukkan bahwa rata-rata penerimaan dalam satu kali masa tanam adalah $\mathrm{Rp}$ 11.312.100,00. Ini menandakan bahwa usahatani padi sawah yang dilakukan di Desa Gunungan, Kecamatan Kartoharjo, Kabupaten Magetan memberikan keuntungan karena produksi nyata (riil) jauh di atas BEP. Apabila melihat tingkat kelayakan maka usahatani padi sawah di Desa Gunungan, Kecamatan Kartoharjo, Kabupaten Magetan layak dikembangkan karena penerimaan riil lebih besar daripada BEP penerimaan yaitu $\mathrm{Rp} 11.312 .100,00$ lebih besar daripada $\mathrm{Rp}$ 7.494.000,00. Seperti yang dikatakan Suratiyah (2009), 
bahwa evaluasi kelayakan usahatani dapat didasarkan pada beberapa kategori dan dapat dikatakan layak apabila memenuhi persyaratan yaitu jumlah penerimaan lebih besar dari BEP penerimaan yang ada.

\section{b. BEP Produksi}

$$
\begin{aligned}
\mathrm{AVC} & =\frac{V C}{Y} \\
& =\frac{R p 5.317 .000,00}{61,33 \mathrm{kw}} \\
& =\mathrm{Rp} 86.694,00 \\
& =\mathrm{Rp} 87.000,00 / \mathrm{kw} \\
\text { BEP Produksi } & =\frac{V C}{P-A V C} \\
& =\frac{R p 5.317 .000,00}{R p 392.000,00-R p 87.000,00} \\
& =\frac{R p 5.317 .000,00}{R p 305.000,00} \\
& =17,43 \mathrm{kw}
\end{aligned}
$$

Berdasarkan perhitungan tersebut dapat dilihat bahwa petani padi sawah di Desa Gunungan, Kecamatan Kartoharjo, Kabupaten Magetan, Provinsi Jawa Timur mengalami titik impas atau break even atau tidak untung atau rugi apabila responden dapat memproduksi atau menjual sebesar $17,43 \mathrm{kw}$ untuk satu kali masa tanam. Jadi, responden mendapatkan keuntungan apabila mereka dapat memproduksi atau menjual lebih dari 17,43 kw. Dan responden akan mengalami kerugian apabila hanya mampu memproduksi atau menjual dibawah 17,43 kw.

Data yang ada menunjukkan bahwa rata-rata produksi dalam satu kali masa tanam adalah $61,33 \mathrm{kw}$. Ini menandakan bahwa usahatani padi sawah yang dilakukan di Desa Gunungan, Kecamatan Kartoharjo, Kabupaten Magetan memberikan keuntungan karena produksi nyata (riil) jauh diatas BEP. Apabila melihat tingkat kelayakan maka usahatani ini layak dikembangkan karena produksi riil lebih besar BEP yaitu 61,33 kw > 17,43 $\mathrm{kw}$. Seperti yang dikatakan Suratiyah (2009), bahwa evaluasi kelayakan usahatani dapat didasarkan pada beberapa kategori dan dapat dikatakan layak apabila memenuhi persyaratan yaitu jumlah produksi lebih besar dari BEP produksi yang ada.

\section{c. BEP Harga}

$$
\begin{aligned}
\text { BEP Harga } & =\frac{T C}{Y} \\
& =\frac{\operatorname{Rp} 11.312 .100,00}{61,33 \mathrm{kw}} \\
& =\operatorname{Rp} 184.446,00 \\
& =\operatorname{Rp} 184.500,00
\end{aligned}
$$

Berdasarkan perhitungan tersebut dapat dilihat bahwa petani padi sawah di Desa Gunungan, Kecamatan Kartoharjo, Kabupaten Magetan mengalami titik impas atau break even atau tidak untung atau rugi apabila responden dapat menjual dengan harga Rp 184.500,-/kw dengan jumlah produksi sebanyak 17,43 kw (BEP Produksi). Jadi, responden mendapatkan keuntungan apabila mereka dapat menjual dengan harga lebih dari Rp 184.500,-/kw. Dan responden akan mengalami kerugian apabila hanya mampu menjual dibawah Rp 184.500,-kw.

Data yang ada menunjukkan bahwa harga jual rata-rata dalam satu kali masa tanam adalah $\mathrm{Rp}$ 392.000,-/kw. Ini menandakan bahwa usahatani padi sawah yang dilakukan di Desa Gunungan, Kecamatan Kartoharjo, Kabupaten Magetan memberikan keuntungan karena produksi nyata (riil) jauh di atas BEP.

\section{d. BEP Luas}

$$
\begin{aligned}
\text { BEP Luas } & =\frac{\text { Produksi BEP }}{\text { Produksi Riil }} \times \text { luas lahan } \\
& =\frac{17,43 \mathrm{kw}}{61,33 \mathrm{kw}} \times 0,90 \mathrm{ha} \\
& =0,2557 \mathrm{ha} \\
& =0,26 \mathrm{ha}
\end{aligned}
$$

Berdasarkan perhitungan tersebut dapat dilihat bahwa luas lahan yang dimiliki responden padi sawah di Desa Gunungan, Kecamatan Kartoharjo, Kabupaten Magetan mengalami titik impas atau break even apabila responden memiliki lahan sebesar 0,26 ha. Jadi, responden mendapatkan keuntungan apabila mereka memiliki lahan lebih dari 0,26 ha. Dan responden akan mengalami kerugian apabila hanya memiliki lahan kurang dari 0,26 ha. Data yang ada menunjukkan 
bahwa besaran lahan rata-rata yang dimiliki responden adalah 0,90 ha. Ini menandakan bahwa usahatani padi sawah yang dilakukan di Desa Gunungan, Kecamatan Kartoharjo, Kabupaten Magetan, Provinsi Jawa Timur memberikan keuntungan karena luas lahan riil jauh diatas BEP.

\section{Analisis Kelayakan}

Untuk menghitung analisis kelayakan digunakan rumus Revenue Cost Ratio (R/C Ratio) dengan rumus :

$$
\begin{aligned}
\text { R/C Ratio } & =\frac{R}{C} \\
& =\frac{\operatorname{Rp} 24 \cdot 118 \cdot 000,00}{\operatorname{Rp} 11 \cdot 312 \cdot 100,00} \\
& =2,13
\end{aligned}
$$

Berdasarkan perhitungan $\mathrm{R} / \mathrm{C}$ ratio tersebut diperoleh angka 2,13, dimana angka 2,13 tersebut memiliki nilai yang lebih dari 1. Apabila lebih dari 1 maka memenuhi kriteria dalam melakukan usahataninya. Maka dari itu, usahatani padi sawah yang dilakukan di Desa Gunungan, Kecamatan Kartoharjo, Kabupaten Magetan, Provinsi Jawa Timur telah efisien.

\section{SIMPULAN}

Berdasarkan hasil penelitian dan analisis usahatani padi sawah yang telah dilakukan di Desa Gunungan, Kecamatan Kartoharjo, Kabupaten Magetan, Provinsi Jawa Timur pada MT I bulan Januari sampai dengan bulan April 2018 dapat diperoleh kesimpulan sebagai berikut:

1. Besar analisis biaya, penerimaan dan pendapatan usahatani padi sawah di Kabupaten Magetan, Jawa Timur :

a. Rata- rata biaya usahatani padi sawah yang dilakukan di Desa Gunungan, Kecamatan Kartoharjo, Kabupaten Magetan, Provinsi Jawa Timur pada MT I bulan Januari sampai dengan bulan April 2018 dengan rata-rata luas lahan sebesar 0,90 hektar adalah $\mathrm{Rp}$ 11.312.100,00, dengan rata-rata biaya variabel sebesar $\mathrm{Rp}$
5.317.000,00 dan rata-rata biaya tetap sebesar Rp 5.995.100,00.

b. Rata- rata penerimaan usahatani padi sawah yang dilakukan di Desa Gunungan, Kecamatan Kartoharjo, Kabupaten Magetan, Provinsi Jawa Timur pada MT I bulan Januari sampai dengan bulan April 2018 adalah sebesar Rp 24.118.000,00.

c. Rata- rata pendapatan usahatani padi sawah yang dilakukan di Desa Gunungan, Kecamatan Kartoharjo, Kabupaten Magetan, Provinsi Jawa Timur pada MT I bulan Januari sampai dengan bulan April 2018 adalah sebesar Rp12.805.900,00.

2. Kelayakan usahatani :

a. Nilai Break-Even Point (BEP) penerimaan usahatani padi sawah yang dilakukan di Desa Gunungan, Kecamatan Kartoharjo, Kabupaten Magetan, Provinsi Jawa Timur pada MT I bulan Januari sampai dengan bulan April 2018 adalah sebesar Rp 7.494.000,00. Petani mendapatkan penerimaan sebesar Rp 12.805.900,00. Hal ini mengindikasikan bahwa petani mendapat keuntungan.

b. Nilai Break-Even Point (BEP) produksi usahatani padi sawah yang dilakukan di Desa Gunungan, Kecamatan Kartoharjo, Kabupaten Magetan, Provinsi Jawa Timur pada MT I bulan Januari sampai dengan bulan April 2018 adalah sebesar 17,43 kw. Petani dapat memproduksi sebanyak 61,33 kw. Hal ini mengindikasikan bahwa petani mendapat keuntungan.

c. Nilai Break-Even Point (BEP) harga usahatani padi sawah yang dilakukan di Desa Gunungan, Kecamatan Kartoharjo, Kabupaten Magetan, Provinsi Jawa Timur pada MT I 
bulan Januari sampai dengan bulan April 2018 adalah sebesar Rp 184.500,00/kw. Petani dapat menjual dengan rata-rata harga $\mathrm{Rp}$ 392.000,00. Hal ini mengindikasikan bahwa petani mendapat keuntungan.

d. Nilai Break-Even Point (BEP) luas usahatani padi sawah yang dilakukan di Desa Gunungan, Kecamatan Kartoharjo, Kabupaten Magetan, Provinsi Jawa Timur pada MT I bulan Januari sampai dengan bulan April 2018 adalah sebesar 0,26 ha. Petani memiliki luas lahan rata-rata sebesar 0,90 ha. Hal ini mengindikasikan bahwa petani mendapat keuntungan.

e. Untuk menganalisis kelayakan usahatani dilakukan dengan menghitung R/C Ratio yang diperoleh angka sebesar 2,13, dimana angka 2,13 tersebut memiliki nilai yang lebih dari 1. Apabila lebih dari 1 maka memenuhi kriteria dalam melakukan usahataninya. Maka dari itu, usahatani padi sawah yang dilakukan di Desa Gunungan, Kecamatan Kartoharjo, Kabupaten Magetan, Provinsi Jawa Timur telah efisien.

Berdasarkan hasil penelitian dan analisis usahatani padi sawah yang telah dilakukan di Desa Gunungan, Kecamatan Kartoharjo, Kabupaten Magetan, Provinsi Jawa Timur pada MT I bulan Januari sampai dengan bulan April 2018, maka saran yang dapat diberikan adalah :

1. Karena banyaknya penyakit tanaman yang ada seperti potong leher (biji padi sawah sudah keluar tetapi tidak ada isinya), kuningan (tanaman rusak karena kebanyakan air), hama wereng, walang sangit, belalang, ulat maka petani harus lebih aktif lagi didalam mencari informasi untuk menanggulanginya agar produksi yang ada lebih maksimal.
2. Sebaiknya pemerintah memberikan solusi terkait dengan persediaan pupuk yang terbatas dan harga yang diberikan cukup mahal. Maka dari itu, alangkah lebih baik apabila pemerintah mencarikan solusi yang tepat untuk petani dengan cara menambah pasokan pupuk yang ada di pasaran dan menurunkan harga yang ada. Selain itu agar semakin banyaknya diadakan subsidi pupuk gratis untuk petani.

\section{DAFTAR PUSTAKA}

Balai Besar Penelitian Tanaman Padi. 2017. Syarat Tumbuh Tanaman Padi Gogo. Balitbangtan. Kementrian Pertanian.

Darus, Saipul Bahri dan Ujang Paman. 2015. Analisis Ekonomi Usahatani Padi Sawah di Kecamatan Rambah Samo, Kabupaten Rokan Hulu. Jurnal Dinamika Pertanian Volume XXX Nomor 2 Agustus 2015 (171176).

Jawa Timur, BPS. 2017. Provinsi Jawa Timur Dalam Angka. BPS Provinsi Jawa Timur. Jawa Timur.

Kementrian Pertanian. 2016. Outlook Komoditas Pertanian Tanaman Pangan. Pusat Data dan Sistem Informasi Pertanian.

Keukama, Matheus Frynardo. 2017. Analisis Pendapatan Usahatani Padi Varietas Ciherang dengan menggunakan Sistem Tanam Legowo Jajar 2:1 (Studi Kasus di Subak Sangempel, Desa Bongkasa, Kecamatan Abiansemal, Kabupaten Badung. E-Jurnal Agribisnis dan Agrowisata Vol.6 No.1 Januari 2017

Magetan, BPS. 2017. Kabupaten Magetan Dalam Angka. BPS Kabupaten Magetan. Magetan.

Magetan, BPS. 2017. Kecamatan Kartoharjo Dalam Angka. BPS Kabupaten Magetan. Magetan. 
Noor, Juliansyah. 2001. Metodologi Penelitian : Skripsi, Tesis, Disertasi dan Karya Ilmiah. Kencana. Jakarta.

Ohen, S.B dan Ajah E.A. 2015. Cost and Return Analysis in Small Scale Rice Production In Cross River State Nigeria. International Research Journal of Agricultural Science and Soil Science. Vol. 5(1): 22-27.

Prasetya, Hery dan Lukiastuti, Fitri. 2009. Manajemen Operasi. Media Pressindo. Yogyakarta.
Soekartawi. 2002. Analisis Usaha Tani. UIPress. Jakarta.

Sugiyono. 2017. Metode Penelitian Kualintatif, Kualitatif dan $R \& D$. CV Alfabeta. Bandung.

Suratiyah, Ken. 2006. Ilmu Usahatani. Penebar Swadaya. Jakarta.

Suratiyah, Ken. 2009. Ilmu Usahatani. Penebar Swadaya. Jakarta.

Suratiyah, Ken. 2015. Ilmu Usahatani (Edisi Revisi). Penebar Swadaya. Jakarta.

*Dosen di Program Studi Agribisnis Fakultas Pertanian Universitas Negeri Sebelas Maret Surakarta

(Email : vionaadezarahma@gmail.com) 